\title{
US research said to have provided basis of Britain's hydrogen bomb
}

Washington. A new history of British, French and Chinese nuclear weapons suggests that the British nuclear programme depended considerably more heavily on US research, development and testing than previously acknowledged.

The authors of the 500-page survey, published in Washington today (24 March) by the Natural Resources Defense Council (NRDC), say that Britain's first two attempts to detonate a hydrogen bomb in May and June 1957 were unsuccessful, despite claims at the time in the British press and by prime minister Harold Macmillan.

The survey also says that Britain's own H-bomb design was discreetly abandoned after 1958, when the United States and United Kingdom resumed nuclear weapons collaboration. It claims that nuclear weapons subsequently deployed by Britain were "nearly direct copies" of US designs.

But some British historians dispute this theory, saying that it may be based on incorrect assumptions about how much testing is needed to perfect a nuclear weapon. They say that available knowledge of the earliest British nuclear weapons demonstrates a willingness to deploy weapons after only a

handful of tests, without the extensive testing programmes favoured by the United States and France.

The NRDC survey suggests that the WE 177 bomb, the Royal Air Force's main nuclear weapon since it entered service in 1966 , is basically a UK-manufactured variant of a US design.

Survey co-author Stan Norris says there are several current theories about the origins

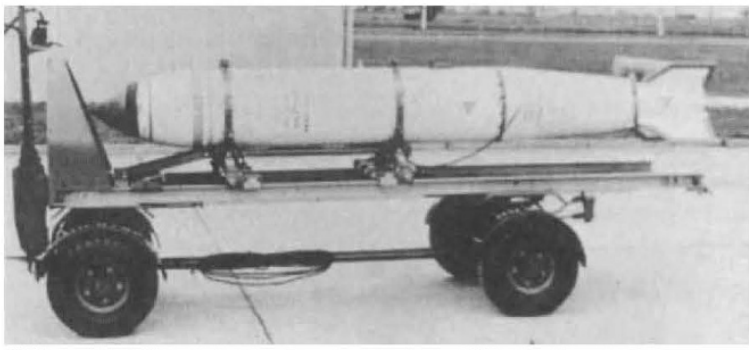

Britain's WE 177 bomb: based on US design?

of the WE 177 . He argues that the paucity of UK tests - only four were held in the crucial period 1962-1965 - undermines the claims that the bomb was an original British design.

Instead, he suggests that successive versions of the WE 177 were based on the American B57 and B61 weapons respectively. In quantitative terms he estimates

\section{Hammersmith celebrates a reprieve}

London. The British government has backed away from a decision to merge the Hammersmith Hospital and the Charing Cross Hospital on a single site. Such a decision could have a significant impact on two of Britain's leading biomedical research institutions, the Royal Postgraduate Medical School (RPMS) and the Medical Research Council's (MRC's) new Clinical Sciences Centre, both of which are currently based at Hammersmith (see Nature, 368, 176; 1993).

Mrs Virginia Bottomley, the secretary of health, announced on Monday that she had approved plans to combine the two hospitals under a single administrative trust, to be chaired by Sir Christopher Bland, the current chairman of the Hammersmith and Queen Charlotte's Hospital Special Health Authority.

Bottomley said that the joint trust, which will be responsible for working out a development plan for the two institutions, offered "the best way to enhance the qualities and reputation of its constituent hospitals." But she also said that it was likely to continue to operate from its main sites "for the foreseeable future".

The decision was warmly welcomed by both scientists and administrators at the Hammersmith Hospital, who had been fighting a vigorous campaign to prevent being moved to the site of the Charing Cross Hospital. The dean of the RPMS, Sir Colin Dollery, said that the two hospitals would now "begin to examine the options for enhancing treatment and research on both sites."

David Evered, the second secretary of the MRC, was more cautious. While describing the trust as "an important step towards the future" of the hospitals, he emphasized that "full provision [is needed] from the outset for the necessary capital sums for facilities on both sites."

The government's announcement provided little indication as to whether such sums are likely to be made available. Indeed some fear it will have done little to lift the planning blight likely to remain hanging over research programmes at the Hammersmith until its future has been definitively decided. that the WE 177 "had $80-90$ per cent commonality with the American bomb".

But John Simpson of the Mountbatten Centre for International Studies at Southampton University, a leading historian of the British atom bomb programme, disagrees. He still believes the WE 177 was a British design based mainly on tests conducted before a three-year nuclear test moratorium began in 1958. Simpson says the British were thinking about the WE 177 as early as 1957 , and that they did not feel they needed the kind of test programmes that the United States conventionally used. "There was a view that where the Americans took seven or eight tests, the British would take one," he says.

However both Simpson and Norris acknowledge that they remain ignorant of what really happened. The intense secrecy that has surrounded the British $\mathrm{H}$-bomb programme has begun to lift slightly; earlier this year, for example, the Public Records Office at Kew released data about testing under the 'thirty-year' rule on classified documents.

Key files on Britain's own programme up to 1958 were closed in 1964 , and have therefore only just been released. But data on the British programme after 1958 is unlikely to follow, since neither Britain nor the United States is permitted to release data about each other's role in the collaboration.

The authors of the NRDC survey claim that it is the most comprehensive history and description of the UK weapons programme yet published - an opinion endorsed on the report's sleeve by former US defence secretary Robert McNamara.

Norris claims that Britain obtained its nuclear arsenal "on the cheap" after resuming weapons collaboration with the United States in 1958. Noting the secret problems that Britain had with its own hydrogen bomb tests in 1957, the survey claims that the British design was effectively shelved the following year.

He says that their explosive yields of 200-300 kT during tests in May and June 1957 indicate that the second, thermonuclear stage of the devices did not work. Only later, in November, did Britain succeed in detonating a genuinely thermonuclear device in which a large proportion of the energy released came from the fusion of hydrogen.

British, French and Chinese Nuclear Weapons is the fifth volume of NRDC's Nuclear Weapons Databook. The previous volumes revealed details of the larger nuclear weapons industries of the United States and the Soviet Union. Colin Macilwain 